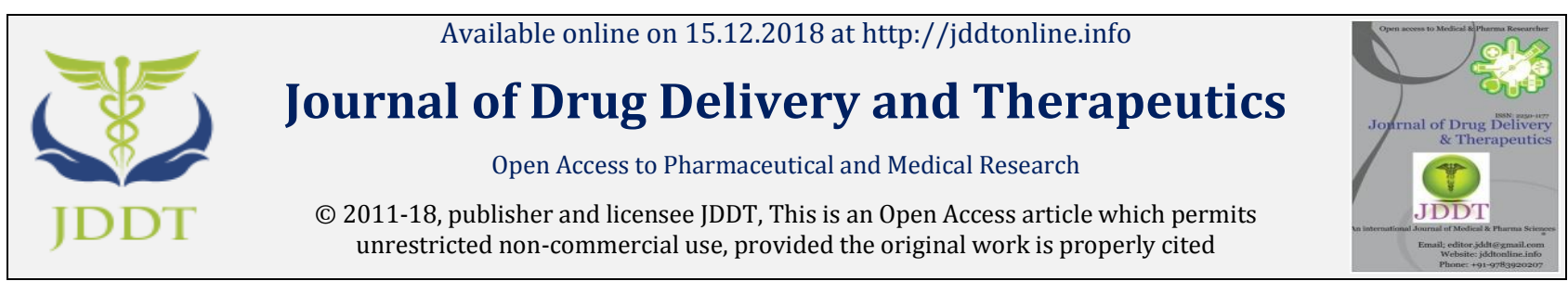

Open $\overbrace{\text { Access }}$

Research Article

\title{
Single dose oral toxicity study of ethanolic extract from inflorescence of Casuarina equisetifolia in Wistar rats
}

\author{
O. Umamaheswar Rao*1 and M. Chinna Eswaraiah ${ }^{2}$ \\ ${ }^{1}$ Research Scholar, JNTUH, Kukatpally, Hyderabad - 500085, Telangana, India \\ ${ }^{2}$ Principal, , Anurag Pharmacy College, Kodad, Nalgonda Dt, Telangana, India
}

\begin{abstract}
The purpose of the study was to evaluate the single dose oral toxicity of the ethanolic extract from inflorescence of Casuarina equisetifolia, Family: Casuarinaceae in female Wistar Rats. The acute toxicity study was carried out based on Organization for Economic Co-operation and Development (OECD) Test Guideline 423. However, this plant safety evaluation data was not available so, selected the starting dose from 300 $\mathrm{mg} / \mathrm{kg}$ body weight. The animals were orally administered a single dose of $300 \mathrm{mg} / \mathrm{kg}$ body weight and followed by $2000 \mathrm{mg} / \mathrm{kg}$ body weight in next step. Signs of toxicity and mortality were observed after $30 \mathrm{~min}, 1,2,4$ and $24 \mathrm{~h}$ of administration of the extract and once daily for 14 days. There was no mortality in the tested animals and no abnormal clinical signs were observed related to test item. No abnormalities were detected in gross pathology observations in all the rats at both the dose levels. Based on observations of the present study, it can be concluded that the $\mathrm{LD}_{50}$ of ethanolic extract from inflorescence of Casuarina equisetifolia is greater than $2000 \mathrm{mg} / \mathrm{kg}$ body weight and can be classified as Category 5; however, further studies are needed to confirm long term toxicities.
\end{abstract}

Keywords: Acute oral toxicity, ethanolic extract from inflorescence of Casuarina equisetifolia, LD $50,0 E C D$ Test Guideline, Wistar Rat.

Article Info: Received 13 Oct 2018; Review Completed 24 Nov 2018; Accepted 27 Nov 2018; Available online 15 Dec 2018

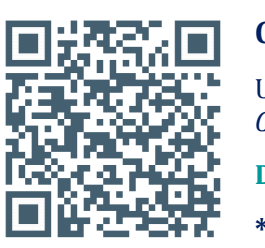

Cite this article as:

Umamaheswar Rao 0, Chinna Eswaraiah M, Single dose oral toxicity study of ethanolic extract from inflorescence of Casuarina equisetifolia in Wistar rats, Journal of Drug Delivery and Therapeutics. 2018; 8(6-s):44-47

DOI: http://dx.doi.org/10.22270/jddt.v8i6-s.2075

*Address for Correspondence:

O. Umamaheswar Rao, Research Scholar, JNTUH, Kukatpally, Hyderabad - 500085, Telangana, India

\section{INTRODUCTION}

Plants have been extensively used as medicines since a thousand years ago and the use of herbal products should be based on scientific origin in order to make sure the plants are safe to consume ${ }^{1}$. However, the most commonly used herbal formulae have no indications of quality, safety and efficacy ${ }^{2}$. Unfortunately, many people underestimate the toxicity of natural products and use them without further scientifically testing. Plants or drugs must be proven to be safe before they could be used as medicines. A key stage in ensuring the safety of drugs is to conduct toxicity tests in appropriate animal models, and acute toxicity studies are just one of a battery of toxicity tests that are used ${ }^{3}$.

As per the OECD test guidelines, in order to establish the safety of a new drug, toxicological studies are very essential in animals like mice, rat, guinea pig, dog, rabbit, etc., under various conditions of drug. Regulatory authorities do not allow the use of drug clinically without its clinical trial which is proceeded by toxicity studies ${ }^{4}$. Acute oral toxicity refers to those adverse effects occurring following oral administration of a single dose of a substance, or multiple doses given within 24 hours $^{5}$.
Objective of the study was to identify a dose causing major adverse effects and an estimation of the minimum dose causing lethality, according to the regulatory guidelines ${ }^{6}$.

Casuarina equisetifolia belongs to the family Casuarinaceae is found in the dry hill sides and open forests of India, Sri Lanka and Australia. The phenolic compounds from the needles (branchlets) and bark showed significant antioxidant activity. Bark is having activities like astringent, in stomacheache, diarrhea, dysentery and nervous disorders. Seeds are anthelmintic, antispasmodic and antidiabetic. Extracts of leaves exhibit anticancer properties. The needles in decoction form used as lotion for swelling and also used in the treatment of cough and ulcers. The extracts of the fruits, stem and leaves are reported to have anti microbial activity. The extracts of the areal parts and stem is reported to have angiotensin-converting enzyme inhibition activity ${ }^{7}$.

The present study has been undertaken to estimate the toxic effects of ethanolic extracts from inflorescence of Casuarina equisetifolia in female Wistar Rats at the dosage of $300,2000 \mathrm{mg} / \mathrm{kg}$ body weight of an animal for a period of 14 days using OECD 423, observation and results were 
recorded accordingly and were reported here to present publicly.

\section{MATERIALS AND METHODS}

\section{MATERIALS}

\section{Collection and preparation of ethanolic extract from} inflorescence of Casuarina equisetifolia

The dried inflorescence was collected in bulk from Padmabhushan Dr. B.V. Raju foundation, Vishnupur, Bhimavaram, West Godavari (District), A.P., India. Then the debris and leaves were removed from the collected material and dried in shade. The pollen grains were separated from inflorescence. It was coarsely grounded in a mixer. The powder was extracted by continuous hot extraction using the Soxhlet apparatus at a temperature of $78^{\circ} \mathrm{C}$ for $48 \mathrm{~h}$ using $95 \%$ ethanol and then evaporating to dryness under shade (chloroform was used as a preservative while drying). The extract was collected and preserved in a desiccator for further studies.

The plant material was identified and authenticated on 18/01/2013 by Taxonomist, Prof. Dr. K. Madhava chetty, S.V. University, Tirupathi, India, Voucher reference number is 2983.

\section{Animals}

The female (nulliparous and non-pregnant) Wistar rats weighing between 164.41 - $191.30 \mathrm{~g}$ of 8-12 weeks old were used for this study. The animals were procured from Sanzyme Limited, Hyderabad, India. The animals were acclimatized for 7 days prior to start an experiment in polypropylene cages with paddy husk as bedding. Animals were housed at a temperature of $23 \pm 2^{\circ} \mathrm{C}$ and relative humidity of $50 \pm 20 \%$. A $12: 12$ light: day cycle was followed. The animals were fed with standard pellet feed and the food was withdrawn 15-18 h before the experiment, although water was allowed ad libitum. The animals used for the experiment were approved by Institutional animal ethics committee (IAEC) of the Anurag Pharmacy College, Kodad, Nalgonda D.t, Telangana, India.

\section{Identification of Animals}

After acclimatization, tail marking was done by using nontoxic ink for animals and arranged the cage label contained the following details: Type of study, extract Name, Animal strain, Dose, Step details, Sex, Animal No.

\section{Body Weight Difference}

During the time of dosing, Body weight difference of the animals was not exceeded $\pm 20 \%$ of mean weight of each set of animals (previously dosed animals).

\section{Mode of administration}

The extract was administered in a single dose by gavage using specially designed oral needle for rat.

\section{Justification for Route of Administration}

Oral route was chosen, as it is one of the recommended routes of exposure to humans.

\section{Test substance administration volume}

The administration volume was $10 \mathrm{~mL} / \mathrm{kg}$ body weight of the animal. Based on the body weight of the animal on the day of treatment, the quantity of the ethanolic extract of Casuarina equisetifolia was calculated.

\section{METHOD}

As per OECD Guideline 423, two types of acute oral toxicity tests i.e. limit test and main test. The limit test is primarily used in situations where the experimenter has information indicating that the test material is likely to be nontoxic, i.e., having toxicity below regulatory limit doses $^{6}$. However, in those situations where there is little or no information about its toxicity, or in which the test material is expected to be toxic, only the main test should be performed, in this experiment the safety related literature was not available so, main study was performed with the starting dose of $300 \mathrm{mg} / \mathrm{kg}$ body weight with three animals (see OECD Test Guideline Annex 2c6 Figure 1).

\section{Experimental Design, Extract Formulation Preparation and Dosing:}

Prior to oral administration of ethanolic extract from inflorescence of Casuarina equisetifolia (for Step I \& Step II - $300 \mathrm{mg} / \mathrm{kg}$ body weight and for Step III \& Step IV - 2000 $\mathrm{mg} / \mathrm{kg}$ body weight), the animals were fasted overnight for 15-18 $\mathrm{h}$ and up to 3-4 $\mathrm{h}$ post dosing (see Table: 1 ). 


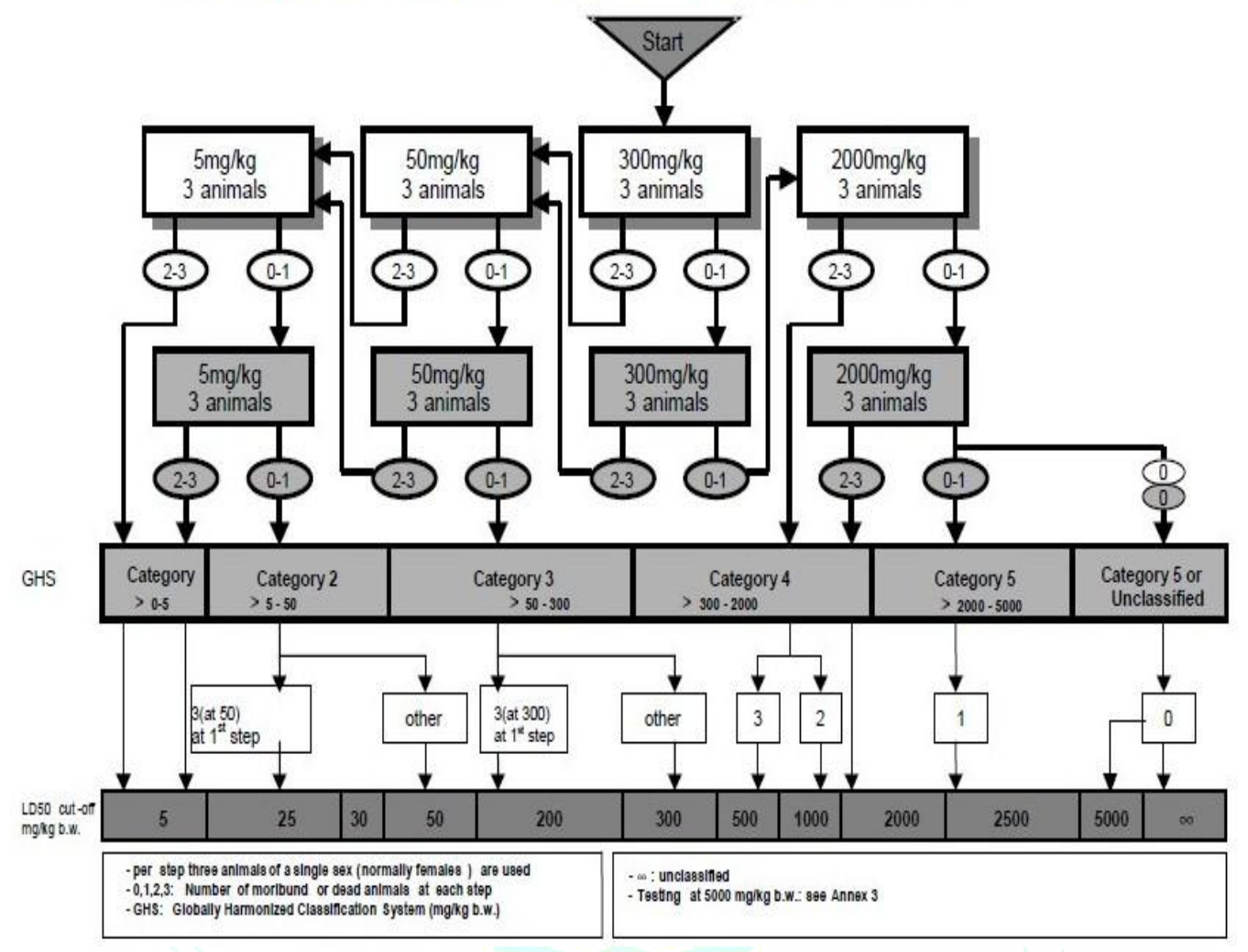

Figure 1: OECD Test Guideline Annex 2c $c^{6}$

Table: 1 Experimental Design

\begin{tabular}{|c|c|c|c|c|}
\hline Step & $\begin{array}{c}\text { Dose of ethanolic extract from inflorescence } \\
\text { of Casuarina equisetifolia (mg/kg b.wt.) }\end{array}$ & $\begin{array}{c}\text { No. of } \\
\text { Animals }\end{array}$ & Sex & $\begin{array}{c}\text { Animal } \\
\text { Number }\end{array}$ \\
\hline Step I & 300 & 3 & Female & $1-3$ \\
\hline $\begin{array}{c}\text { Step II } \\
\text { (Confirmatory) }\end{array}$ & 300 & 3 & Female & $4-6$ \\
\hline Step III & 2000 & 3 & Female & $7-9$ \\
\hline $\begin{array}{c}\text { Step IV } \\
\text { (Confirmatory) }\end{array}$ & 2000 & 3 & Female & $10-12$ \\
\hline
\end{tabular}

\section{Dose Formulation Preparation}

The required amount of ethanolic extract $(300 \mathrm{mg}$ and $2000 \mathrm{mg}$ ) was weighed and transferred in mortar. The extract was triturated with 1\% CMC and then the suspension was completely transferred to a $10 \mathrm{~mL}$ volumetric flask. The $10 \mathrm{~mL}$ formulation was prepared freshly before oral administration. A dose volume of 10 $\mathrm{mL} / \mathrm{kg}$ body weight was maintained in the study period.

\section{Dose Administration}

The formulated extract was orally administered to animals at the respective steps (Step I \& Step II - $300 \mathrm{mg} / \mathrm{kg}$ body weight and for Step III \& Step IV - $2000 \mathrm{mg} / \mathrm{kg}$ body weight) by oral gavage needle in a single dose using disposable syringes.

\section{Observations}

Body weights were taken for all the animals, recorded on the first day of dosing and thereafter once every week and at the time of termination. Clinical signs were observed for each animal at regular intervals (at 30 minutes, 1, 2, and 4 h) on the day of dosing and once daily for 14 days. Observations included changes in skin and fur, eyes and mucous membranes and behavioral pattern. Attention was given for observations of tremors, convulsions, salivation, diarrhea, lethargy, sleep, coma and mortality were observed daily up to 14 days. On day 15, all the survived animals were terminally sacrificed by the carbon dioxide asphyxiation for Gross pathological examination (external and internal) for safety assessment.

\section{RESULTS AND DISCUSSION}

\section{General Clinical Observations, Mortality \& Mortality}

No Mortalities were observed in all the animals administered with ethanolic extracts from inflorescence of Casuarina equisetifolia at 300 and $2000 \mathrm{mg} / \mathrm{kg}$ b. wt. and no treatment related clinical signs were observed in all the Steps (Step I, Step II, Step III and Step IV), (see Table 2). 
Table 2: Observation for the Test at 300 (Step I \& Step II) \& at 2000 (Step III \& Step IV) mg/kg Body Weight

\begin{tabular}{|c|c|c|c|c|c|c|c|c|}
\hline \multicolumn{9}{|c|}{$\begin{array}{c}\text { Observation for the Test at } 300 \text { (Step I \& Step II) \& at } 2000 \\
\text { (Step III \& Step IV) mg/kg Body Weight }\end{array}$} \\
\hline Observations & $30 \mathrm{~min}$. & $1 \mathrm{~h}$ & $2 \mathrm{~h}$ & $4 \mathrm{~h}$ & $24 \mathrm{~h}$ & $48 \mathrm{~h}$ & 1 week & 2 week \\
\hline Skin and Fur & $\mathrm{N}$ & $\mathrm{N}$ & $\mathrm{N}$ & $\mathrm{N}$ & $\mathrm{N}$ & $\mathrm{N}$ & $\mathrm{N}$ & $\mathrm{N}$ \\
\hline Eyes & $\mathrm{N}$ & $\mathrm{N}$ & $\mathrm{N}$ & $\mathrm{N}$ & $\mathrm{N}$ & $\mathrm{N}$ & $\mathrm{N}$ & $\mathrm{N}$ \\
\hline Mucous Membrane & $\mathrm{N}$ & $\mathrm{N}$ & $\mathrm{N}$ & $\mathrm{N}$ & $\mathrm{N}$ & $\mathrm{N}$ & $\mathrm{N}$ & $\mathrm{N}$ \\
\hline Salivation & $\mathrm{N}$ & $\mathrm{N}$ & $\mathrm{N}$ & $\mathrm{N}$ & $\mathrm{N}$ & $\mathrm{N}$ & $\mathrm{N}$ & $\mathrm{N}$ \\
\hline Lethargy & Nil & Nil & Nil & Nil & Nil & Nil & Nil & Nil \\
\hline Sleep & $\mathrm{N}$ & $\mathrm{N}$ & $\mathrm{N}$ & $\mathrm{N}$ & $\mathrm{N}$ & $\mathrm{N}$ & $\mathrm{N}$ & $\mathrm{N}$ \\
\hline Coma & Nil & Nil & Nil & Nil & Nil & Nil & Nil & Nil \\
\hline Convulsions & Nil & Nil & Nil & Nil & Nil & Nil & Nil & Nil \\
\hline Tremors & Nil & Nil & Nil & Nil & Nil & Nil & Nil & Nil \\
\hline Diarrhea & Nil & Nil & Nil & Nil & Nil & Nil & Nil & Nil \\
\hline Morbidity & Nil & Nil & Nil & Nil & Nil & Nil & Nil & Nil \\
\hline Mortality & Nil & $\mathrm{Nil}$ & Nil & Nil & Nil & Nil & Nil & Nil \\
\hline
\end{tabular}

\section{Body Weights}

All the animals were exhibited a progressive increase in body weight for (Step I \& Step II, Step III and Step IV) throughout the study period, (see Table 3).

Table 3: Mean Body Weights of Step1 to Step IV

\begin{tabular}{|c|c|c|c|}
\hline \multirow{2}{*}{$\begin{array}{c}\text { Step/Dose } \\
\text { (mg/kg b.wt.) (Animal } \\
\text { Number) }\end{array}$} & \multicolumn{3}{|c|}{$\begin{array}{c}\text { Day } \\
\text { (Mean + SD) }\end{array}$} \\
\hline & 1 & 8 & 14 \\
\hline $\begin{array}{c}\text { Step I } / 300 \\
(1,2 \& 3)\end{array}$ & $171.66+4.057$ & $178.46+3.804$ & $186.35+3.771$ \\
\hline $\begin{array}{c}\text { Step II } / 300 \\
(4,5 \& 6)\end{array}$ & $181.10+2.350$ & $188.94+3.141$ & $198.99+3.171$ \\
\hline $\begin{array}{l}\text { Step III/2000 } \\
(7,8 \& 9)\end{array}$ & $169.63+5.215$ & $178.39+8.106$ & $188.55+9.393$ \\
\hline $\begin{array}{l}\text { Step IV/ } 2000 \\
(10,11 \& 12)\end{array}$ & $187.56+3.561$ & $199.53+6.065$ & $208.62+5.706$ \\
\hline
\end{tabular}

\section{Gross Pathology}

After completion of study all the animals were terminally sacrificed by the carbon dioxide $\left(\mathrm{CO}_{2}\right)$ asphyxiation. Gross pathological examination was performed for all the animals (Step I, Step II, Step III and Step IV).

\section{External Findings/Internal Examination}

No Abnormality Detected (NAD) in external observations and internal organs at both dose levels (Step I \& Step II $300 \mathrm{mg} / \mathrm{kg}$ body weight and for Step III \& Step IV - 2000 $\mathrm{mg} / \mathrm{kg}$ body weight).

\section{CONCLUSION}

Based on the above observations in this acute oral toxicity study of ethanolic extract of from inflorescence of Casuarina equisetifolia in Wistar rats, it can be concluded that the LD 50 cut-off value is greater than $2000 \mathrm{mg} / \mathrm{kg}$ body weight and as per Globally Harmonized System for the classification of chemicals (GHS), can be classified as Category 5 . However, further studies are needed to confirm long term toxicities.

Acknowledgement: Authors are sincerely thankful to Dr. K. Madhava Chetty, Plant Taxonomist, Department of Botany, Sri Venkateswara University, Tirupati - 517 502, A.P., India for supplying, Identification and authentication of plant materials.
Conflict of interest: Authors have declared that no conflict of interests exists.

\section{REFERENCES}

1. Sheah Yee Ghan, Jin Han Chin, Yin Yin Thoo, Hip Seng Yim, Chun Wai Ho, Acute Oral Toxicity Study of Aquilaria Crassna and $\alpha$ Tocopherol in Mice, International Journal of Pharmaceutical Sciences and Research, 2016; 7(4):1456-1461.

2. Subhangkar Nandy, Rana Datta, Acute and sub-acute toxicity studies of methanolic leaves extract of Pterospermum acerifolium (L.) Willd in rodents, International Journal of Pharmacy \& Life Sciences, 2012; 3(3):1519-1529.

3. Lalitha P, Shubashini K Sripathi, Jayanthi P, Acute toxicity study of extracts of eichhorniacrassipes (mart.) Solms, Asian Journal of Pharmaceutical and Clinical Research, 2012; 5(4):59-61.

4. Abrar Hussain Mir, Manjusha Sexena, Mohd Yousuf Malla, An acute oral toxicity study of methanolic extract from Tridex procumbensin Sprague Dawley's Rats as per OECD guidelines 423, Asian Journal of Plant Science and Research (Pelagia Research Library), 2013; 3(1):16-20.

5. OECD Guideline for Testing of Chemicals: Acute Oral ToxicityAcute Toxicity Class Method 423. OECD/OCDE, Adopted $17^{\text {th }}$ December. 2001; 1-14.

6. Hari Venkatesh. K.R., Ankur Ptel, Ravi Mundugaru, B. Ravishankar, Evaluation of "YAK001" for safety Profile: Acute Oral Toxicity Study, International research journal of Pharmacy, 2015; 6(8):559-561.

7. Umamaheswar Rao O, Chinna Eswaraiah M, Prabhakar MC, Santhikrupa D, Hepatoprotective activity of aqueous extract from Inflorescence and Pollen Grains of Casuarina equisetifolia against Paracetamol induced Hepatotoxicity in Wistr Rats, International Journal of Pharmaceutical Sciences and Research, 2018; 9(2):743-747. 